\title{
Additive potentials of Zingiber officinale on the aflatoxin secreted in waste- mould feed fed to Clarias gariepinus (burchell, 1822)
}

\author{
O.T. AGBEBI*, A.I. ILESANMI and I. ABDULRAHEEM \\ Department of Aquaculture and Fisheries Management, Federal University of Agriculture, Abeokuta, Ogun \\ State, Nigeria. PMB 2240, Abeokuta, Nigeria, Tel.:+2348037045878, +2348072723153, \\ *Corresponding author, E-mail: agbebi20@yahoo.com.
}

\begin{abstract}
The growth and pathological effect of aflatoxin in waste-mould feeds fed to juvenile Clarias gariepinus and the additive nature of Zingiber officinale was studied. Clarias gariepinus juveniles $(58.19 \pm 1.8 \mathrm{~g})$ were distributed at the rate of 10 per happa net in earthen ponds. There were 5 Treatments with 3 replicates - control diet TRT 1 (Good feed, without mould), TRT 2 (Mould feed only), TRT 3 (60 g of Z. officinale $+1 \mathrm{~kg}$ of mould feed), TRT 4 (30 g of Z. officinale $+1 \mathrm{~kg}$ of mould feed), and TRT5 (10 g of Z. officinale $+1 \mathrm{~kg}$ of mould feed). The fish were fed to satiation at $5 \%$ body weight twice per day for 8 weeks (56 days) and the fish growth parameters measured. There was significant increase $(\mathrm{P}<0.05)$ in mean weight gain of TRT 1, TRT 3, and TRT 4 compare to TRT 2 and TRT 5. The experimental fish at TRT1, TRT 3, TRT 4 and TRT 5 were significantly different $(\mathrm{P}<0.05)$ compared to TRT 2 in weight gain, protein efficiency ratio (PER), feed conversion ratio (FCR), and specific growth rate (SGR). The gills and liver of the control group (TRT1) of fish appeared with single layer of epithelial cells covering the secondary lamellae and uniform distribution of the hepatocytes respectively. In the TRT 2 and TRT 5, there was haemorrhage of the capillaries in the interlamellar space of the gills. Kidney of the fish in the TRT 1, TRT 3 and TRT 4 had normal glomeruli which are not the same with the TRT 2 and TRT 5 . These findings showed that $Z$. officinale has the capacity to suppress the toxic effects of the aflatoxin (secondary metabolites) secreted by the mould feeds on the growth and vital organs of $C$. gariepinus.

() 2013 International Formulae Group. All rights reserved.
\end{abstract}

Keywords: Aflatoxin, Clarias gariepinus, mould feed, Zingiber officinale, treatments.

\section{INTRODUCTION}

The lack of storage facility is one of the major problems in the tropics. This has led to spoilage of food/feed in this region. Fish especially is affected when feeds that are not properly stored is consumed with moulds contaminated food. Moulds are filamentous (fuzzy or dusty appearing) fungi that occur commonly in feedstuffs, including roughages and concentrates. It can infect animals causing a disease referred to as mycosis. Fungal pathogens include: Aspergillus fumigatus, Candida albicans, Candida vaginitis, certain species of Fusarium and others. Aspergillus fumigatus is known to cause mycotic pneumonia, mastitis and abortions and has been recently proposed as the pathogenic agent associated with mycotie hemorrhagic 
bowel syndrome in dairy cattle (Puntenney et al., 2003). Many species of fungi produce mycotoxins in feedstuffs.

Moulds grow with production of mycotoxins on pre-harvest or during storage, transport, processing on feed products (Coulombe, 1993). A blue fluorescent toxin was isolated from moulds and mycelia of Aspergillus spp were observed. Aspergillus $s p$ was soon shown to produce toxic compound(s) that was characterized chemically and biologically and was given the trivial name aflatoxin. Aflatoxin was shown to be very toxic and carcinogenic in some of the test animal species used, and it resulted in a toxic metabolite in milk of dairy cows (Smith, 1997; Fratamico et al., 2008). The discovery of aflatoxin and elucidation of some of its effects led to research on other livestock health and production problems linked with mouldy feedstuffs and to the discovery of additional mycotoxins.

Many medicinal plants are used in therapy of different diseases. Ginger (Zingiber officinale) is example of botanicals which is gaining popularity amongst modern physicians and its underground rhizomes are the medicinally useful part (Mascolo et al., 1989). One of the most popular uses of ginger is its effect on growth rate (Gujral et al., 1978; Saber et al., 2010).

The study aimed at studying the suppressive nature of ginger on inclusion level of the mould feed and to determine its growth effect of the experimental feed on the Clarias gariepinus.

\section{MATERIALS AND METHODS Experimental site and set-up}

The experiment was conducted at the Hepa fish farm, Asero Abeokuta, Ogun State. The eight weeks experiment was carried out in net happa suspended and stabilized in $12 \mathrm{~m}$ x12 m x $1.5 \mathrm{~m}$ earthen pond using kuralon twine tied horizontally into the bottom. The juvenile $C$. gariepinus were obtained from a private farm and acclimatized for two weeks. During the period of acclimatization, the fish were fed diet with $30 \%$ crude protein before the commencement of the experiment. Ten post juveniles fish $(58.19 \pm 1.8 \mathrm{~g})$ (12 weeks old) were randomly distributed into each happa net. These were replicated per treatment and the fishes were fed at 3\% body weight twice daily at 07:00-08:00 hrs and 16:0017:00 hrs.

The feed ingredients were purchased from UNAAB Agro-Allied Company mill, Abeokuta. The feed were left in a store at a temperature between $28-33{ }^{\circ} \mathrm{C}$, relative humidity at $80 \mathrm{mgl}^{-1}$ and kept moistened in a polythene sack for two months to encourage the growth of fungi. The feed ingredients were then mixed together (Table 1), and the total aflatoxin level of the feed was determined using thin layer chromatography (TLC) (AOAC, 2000) at the Poultry and Fish Diseases Diagnosis and Control Laboratory, Animal Care Services Konsult Ltd, Ogun State, Nigeria.

The ginger powder was gotten from a local market in Nigeria. There were 5 treatments, 3 replicates - TRT 1 (Good feedmould free), TRT 2 (Mould feed), TRT 3 (60 $\mathrm{g}$ of ginger $/ \mathrm{kg}$ of mould feed), TRT 4 (30 $\mathrm{g}$ of ginger/kg of mould feed), and TRT5 (10 $\mathrm{g}$ of ginger $/ \mathrm{kg}$ of mould feed). The proximate composition of the ingredients was determined by (AOAC, 2000), the details of which are presented in Table 2. The compounded feed was pelletized using a hand pelletizer with a $2 \mathrm{~mm}$ diameter and dried.

\section{Experimental procedure}

Fish in each treatment were fed with experimental diet at $5 \%$ of their body weight. Weight changes were recorded weekly with a sensitive electronic weighing scale (Meter 
Toledo FB602) and feed adjusted appropriately. At the end of 8 weeks the effect of these experimental diets were observed.

\section{Histopathology examination}

Histopathology examination of the liver, kidney, gills and arboreal respiratory organ were carried out. These organs were examined for both gross and microscopic examinations (Gingerich, 1982)

\section{Growth performance parameters}

The effect of various treatments on growth performance of fish was defined using mean weight gain, average daily growth, specific growth rate, feed conversion ratio, feed efficiency ratio, and protein efficiency ratio.

\section{Mean weight gain}

Mean weight gain was computed as the average weight gained by the experimental fish in the course of the feeding trial.

Mean weight gain $(\mathrm{g})=$ Final mean weight (g) - Initial mean weight (g).

Specific growth rate (SGR)

Specific growth rate, $[\operatorname{SGR}(\% /$ day $)]=$ $100\left(\log W_{2}-\log W_{1}\right) /\left(\mathrm{T}_{2}-\mathrm{T}_{1}\right)$,

where; $W_{1}$ is the weight at time $T_{1}$ and $W_{2}$ is the weight at time at $\mathrm{T}_{2}$.

Table 1: Gross composition of experimental diet.

\begin{tabular}{lc}
\hline Components & Diet (kg) \\
\hline Maize & 5.37 \\
Biscuit Waste meal & 5.00 \\
Indomine & 5.00 \\
Gala & 5.00 \\
Soybean meal & 27.56 \\
Fish meal & 27.56 \\
Groundnut Cake & 14.26 \\
Vitamin C & 0.10 \\
Salt & 0.15 \\
Lysine & 0.25 \\
Methionine & 0.25 \\
Premix* & 1.00 \\
\hline *Contains VitA 4000000IU; Vit D. 800000IU; Vit. E 40000mg; Vit.K3 800mg; Vit.B1 1000 mg; Vit.B2 \\
6000mg; Vit.B6 5000m; Vit. B12 25mg; Niacin 6000mg; Patothenic acid 20000mg; Folic acid 200mg; Folic \\
acid 200mg; Biotin 8mg; Manganese 300000mg; Iron 80000mg; Zinc 20000mg; Cobalt 80mg; Iodine 400mg; \\
Selenium 40mg; Choline 800000mg
\end{tabular}

Table 2: Proximate composition of feed ingredients.

\begin{tabular}{lccccccc}
\hline & $\begin{array}{c}\text { Moisture } \\
\text { content }(\boldsymbol{\%})\end{array}$ & $\begin{array}{c}\text { Dry matter } \\
\text { content }(\boldsymbol{\%})\end{array}$ & $\begin{array}{c}\text { Fat content } \\
(\boldsymbol{\%})\end{array}$ & $\begin{array}{c}\text { Ash } \\
\text { content } \\
(\boldsymbol{\%})\end{array}$ & $\begin{array}{c}\text { Crude } \\
\text { fibre } \\
\text { content } \\
(\boldsymbol{\%})\end{array}$ & $\begin{array}{c}\text { Crude } \\
\text { protein } \\
\text { content } \\
(\boldsymbol{\%})\end{array}$ & $\begin{array}{c}\text { Carbohydrate } \\
\text { content }(\%)\end{array}$ \\
\hline TRT 1 & 5.97 & 94.03 & 17.61 & 10.94 & 4.96 & 39.64 & 21.08 \\
TRT 2 & 8.24 & 91.76 & 16.56 & 10.32 & 4.70 & 37.81 & 22.37 \\
TRT 3 & 8.70 & 91.30 & 16.84 & 10.25 & 4.76 & 37.54 & 21.91 \\
TRT 4 & 9.28 & 90.72 & 16.43 & 10.14 & 4.59 & 37.40 & 21.88 \\
TRT 5 & 9.68 & 90.32 & 16.76 & 10.06 & 4.61 & 37.19 & 21.70 \\
\hline
\end{tabular}




\section{Feed conversion ratio (FCR)}

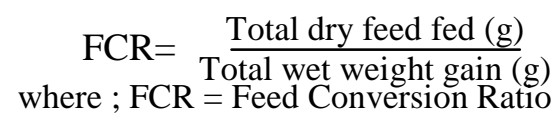

\section{Feed efficiency ratio (FER)}

$$
\begin{gathered}
\text { FER }=\frac{\text { Body weight gain (wet weight g) X } 100}{\text { Feed fed (dry weight g) }} \\
\text { Where, FER }=\text { Feed Efficiency Ratio }
\end{gathered}
$$

\section{Protein efficiency ratio (PER)}

This is the relationship between wet weight gain of fish and the protein content of feed.

$$
\mathrm{PER}=\frac{\text { Wet weight gain }(\mathrm{g})}{\text { Amount of protein fed }(\mathrm{g})}
$$

Where, PER $=$ Protein efficiency ratio

\section{Statistical Analysis}

Data collected were subjected to analysis of variance (SAS Institute, 1999). Duncan's multiple range tests was used to compare means among treatments at a probability level of $5 \%$.

\section{RESULTS AND DISCUSSION}

\section{Feed consumption and Behaviour}

The feed consumption was low at the first week of the experiment. They assumed feeding fully at the second week of the experiment. The fish in the TRT 1 (control) responded normally to the feed. The treatment with TRT 1, TRT 3 and TRT 4 showed good response to the experimental diet after the second week of the experiment. Experimental fish at TRT 2 and TRT 5 showed stressful movement.

\section{Growth response}

Table 3 show the growth response of the fish fed with the different experimental diets. The growth response observed in TRT 1 was better compared to other treatment diets in the experiment. $20 \%$ mortality was recorded in the TRT 5 while there was no mortality in others as a result of the experimental diet. The growth rate was low at the lowest inclusion of ginger.

At the end of 8 weeks experimental period, there was significant difference $(\mathrm{P}<0.05)$ in the weight gained from all the treatments. The feed intake was low in treatments with TRT 3 and TRT 4 while it was high in the TRT 2 . Though the protein intake in the TRT was the highest but the PER was the lowest and significantly different $(\mathrm{P}<0.05)$ from other experimental feed in the group. From the FCR and SGR TRT 3 and TRT 4 seem to be better compared to others in the group.

Table 3: Summary of the growth rate in Clarias gariepinus fed with experimental diet.

\begin{tabular}{lccccc}
\hline & TRT 1 & TRT 2 & TRT 3 & TRT 4 & TRT 5 \\
\hline Initial $(\mathrm{g})$ & $57.66^{\mathrm{a}} \pm 0.88$ & $58.77^{\mathrm{a}} \pm 0.22$ & $58.48^{\mathrm{a}} \pm 0.30$ & $58.03^{\mathrm{a}} \pm 0.76$ & $58.70^{\mathrm{a}} \pm 0.33$ \\
Final $(\mathrm{g})$ & $133.80^{\mathrm{ab}} \pm 11.65$ & $117.53^{\mathrm{a}} \pm 6.47$ & $131.27^{\mathrm{abc}} \pm 3.00$ & $127.27^{\mathrm{c}} \pm 2.57$ & $116.30^{\mathrm{bc}} \pm 3.09$ \\
Weight Gain $(\mathrm{g})$ & $76.17^{\mathrm{a}} \pm 6.54$ & $58.76^{\mathrm{b}} \pm 9.79$ & $72.79^{\mathrm{ab}} \pm 7.96$ & $69.23^{\mathrm{b}} \pm 4.19$ & $57.93^{\mathrm{b}} \pm 4.24$ \\
Feed Intake $(\mathrm{g})$ & $194.54^{\mathrm{ab}} \pm 6.81$ & $207.69^{\mathrm{a}} \pm 1.09$ & $165.37^{\mathrm{bc}} \pm 1.64$ & $141.46^{\mathrm{c}} \pm 1.07$ & $173.21^{\mathrm{abc}} \pm 1.10$ \\
Protein Intake (g) & $77.816^{\mathrm{ab}} \pm 2.77$ & $83.07^{\mathrm{a}} \pm 4.40$ & $66.15^{\mathrm{bc}} \pm 6.58$ & $56.58^{\mathrm{c}} \pm 4.29$ & $69.28^{\mathrm{abc}} \pm 4.43$ \\
PER & $0.98^{\mathrm{a}} \pm 0.06$ & $0.71^{\mathrm{ab}} \pm 0.09$ & $1.05^{\mathrm{a}} \pm 0.20$ & $1.03^{\mathrm{a}} \pm 0.15$ & $0.82^{\mathrm{a}} \pm 0.11$ \\
FCR & $2.61^{\mathrm{a}} \pm 0.31$ & $3.60^{\mathrm{ab}} \pm 0.23$ & $2.60^{\mathrm{a}} \pm 0.56$ & $2.53^{\mathrm{a}} \pm 0.37$ & $3.16^{\mathrm{ab}} \pm 0.44$ \\
SGR & $1.41^{\mathrm{a}} \pm 0.09$ & $1.07^{\mathrm{ab}} \pm 0.11$ & $1.48^{\mathrm{a}} \pm 0.22$ & $1.49^{\mathrm{a}} \pm .22$ & $1.22^{\mathrm{a}} \pm .18$ \\
FER & $0.39^{\mathrm{a}} \pm .02$ & $0.28^{\mathrm{ab}} \pm .038$ & $0.42^{\mathrm{a}} \pm .080$ & $0.41^{\mathrm{a}} \pm .06$ & $0.33^{\mathrm{a}} \pm .045$ \\
Survival (\%) & 100 & 100 & 100 & 100 & 80 \\
\hline \multicolumn{5}{c}{ Means with the same superscript in the same column are not significantly different $(\mathrm{P}>0.05)}$.
\end{tabular}




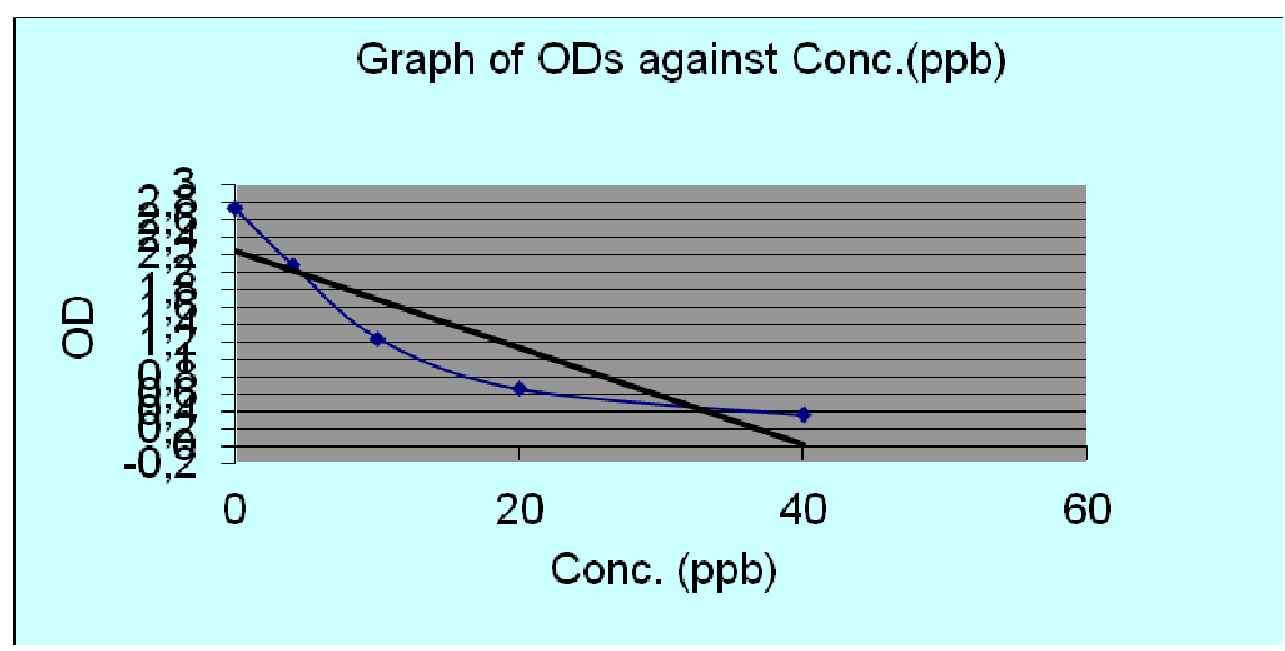

Figure 1: Graph of OD against concentration with the value of total aflatoxin equals $118 \mathrm{ppb}$ $(\mu \mathrm{g} / \mathrm{kg})$.

Moulds are fungi that occur commonly in poorly stored feedstuffs and produce mycotoxins. Aflatoxin is the most significant and toxic compound produced majorly by fungi Aspergillus flavus and A. Parasiticus which represent a serious source of contamination in feeds in many parts of the world.

The $C$. gariepinus used appeared healthy throughout the experimental period even with the treatment containing the mould feed TRT 2. The healthy appearance of $C$. gariepinus juveniles in this study is in contrast to the response observed when Heterobranchus longifilis fed with mould infested feed for 42 days showed low survival rates (Effiong and Alatise, 2009). It has been reported that channel cat fish are resistant to the carcinogenic and acute toxic effects of aflatoxin $\quad B_{1} \quad$ (Hendricks, 1994). The fingerlings of channel cat fish fed with dietary levels of 100,464 , or $2154 \mu \mathrm{g} \mathrm{kg}^{-1}$ aflatoxin $\mathrm{B}_{1}$ for 10 weeks produced no observable behavioral or histological effects (Jantrarotai and Lovell, 1990). It was until the catfish were exposed to $10,000 \mu \mathrm{g} \mathrm{kg}^{-1}$ that sublethal toxicities, including reduced growth were observed.
The low weight gain observed in TRT 2 might be as a result of the level of total aflatoxin secreted by the mould $118 \mathrm{ppb}$ $(\mu \mathrm{g} / \mathrm{kg}$ ) (Figure 1). This is above the $20 \mathrm{ppb}$ action point for total aflatoxin. This supports the observation of Chávez-Sánchez et al. (1994) with young Oreochromis niloticus fed with aflatoxin infected feed, where a clear reduction in growth rate was observed after an experimental period of 25 days. Effiong and Alatise, (2009) studied the effect of mouldinfested feeds on the growth and survival of Heterobranchus longifilis fingerlings in aquaria tanks system and observed the same effect on the growth rate. On the other hand the administration of ginger in the TRT 3 and 4 reflected a significant increase $(\mathrm{P}<0.05)$ in weight gain of experimental fish in comparison with TRT 2 group. This is the same as the findings of Saber et al. (2010) who studied the effect of ginger (Zingiber officinale) upon hepatotoxicity induced in albino rats.

Though there was a significant increase $(\mathrm{P}<0.05)$ in the total feed intake and protein intake of the experimental fish in the TRT2 but these could not reflect in the PER, SGR and FCR of the treatment. This observation is 
likely to be as a result of the reduction in growth rate effects of the secondary metabolite like aflatoxin present in the experimental feed. Heterobranchus longifilis fingerlings shows the same result in the study of Effiong and Alatise (2009) when they were fed with mould infested feed. Also this showed that the exposure of mould feed has a great effect on the C. gariepinus. Eaton and Groopman (1994) also confirm that the extent of disease caused by consumption of aflatoxins depends on the feeding ratio, age, and species of the fish. The result of present study was also similar to that of El-Banna et al. (1992) where Nile tilapia fed with a diet containing $0.1 \mathrm{mg} \mathrm{kg} \mathrm{kg}^{-1}$ aflatoxin $\mathrm{B}_{1}$ for 10 weeks had reduced growth and fish fed with a $0.2 \mathrm{mg} \mathrm{kg} \mathrm{kg}^{-1}$ aflatoxin $\mathrm{B}_{1}$ diet had $16.7 \%$ mortality. Also, a reduction in growth rate has been observed in young Oreochromis niloticus fed with aflatoxin $\mathrm{B}_{1}$-supplemented feed (Chávez-Sánchez et al., 1994). The effects of ginger in the TRT 3 and TRT 4 support the report of (Gujral et al., 1978; Saber et al., 2010) that ginger has an effect on growth rate.

Aflatoxin has been reported to cause varying damages to vital organs in fish this was discovered when the gills, liver and kidney of the experimental fish were observed under microscope. The gills of the control group (TRT 1) of fish appeared with single layer of epithelial cells covering the secondary lamellae. In the TRT 2 and TRT 5 fed fish, there was haemorrhage of the capillaries in the inter-lamellar space. Also prominent was the desquamation of the lamellar epithelial cells (Figure 2).

Likewise kidney of the fish in the TRT 1 (control group), TRT 3 and TRT 4 had normal glomeruli and tubules along with presence of all type of haemopoietic cells, mostly of monocytoid series (Figure 3). This might be as a result of the presence of plant Zingiber officinale (ginger) which possesses some pharmacological activities with its antiinflammatory and antioxidant properties. Ginger extract has hepato-protective effects on liver toxicity (Vasala, 2001; Masniari, 2011). Meanwhile the observation is not the same with the TRT 2 and TRT 5 fish which revealed degrees of degenerative and necrotic changes in the tubular epithelium (Figure 4).

The liver of TRT 2 and TRT 5 fish showed diffuse necrosis of hepatocytes, cells of the liver (Figure 6), which might be as a result of the absence of Zingiber officinale in TRT 2 and the low inclusion level (10 g of ginger/kg of mould feed) in TRT 5. While that of the TRT 1 showed uniform distribution of the hepatocytes as seen in Figure 5. The fish in TRT 3 and TRT 4 has moderate diffuse necrosis of hepatocytes (Figure 7).

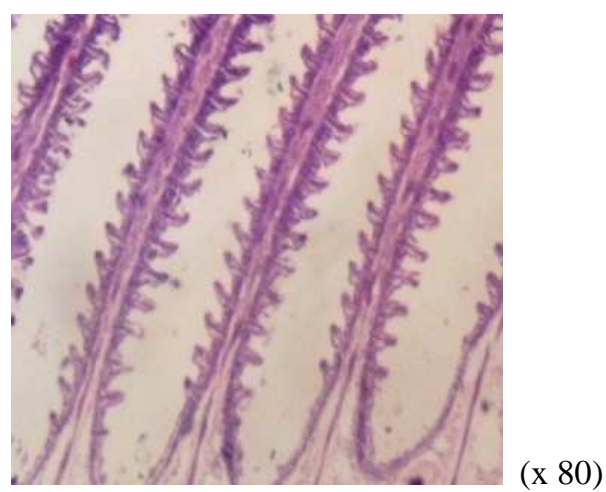

Figure 2a: Gill from TRT 1 (control) appeared with single layer of epithelial cells covering the secondary lamellae. 


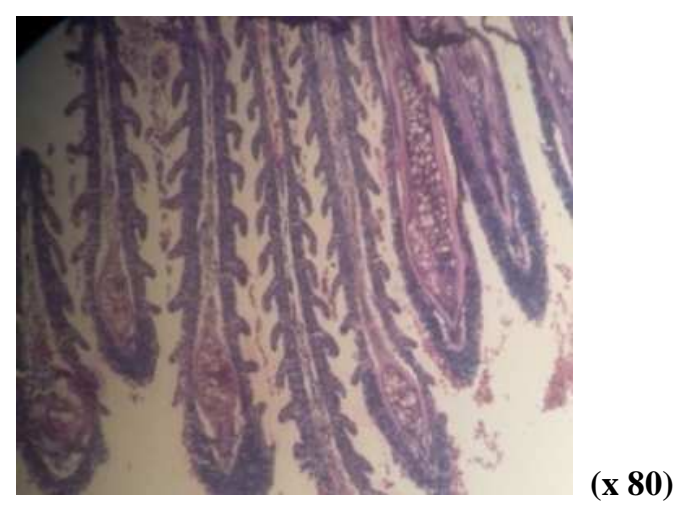

Figure 2b: Gill from TRT 2 shows haemorrhage of the capillaries in the inter-lamellar space.

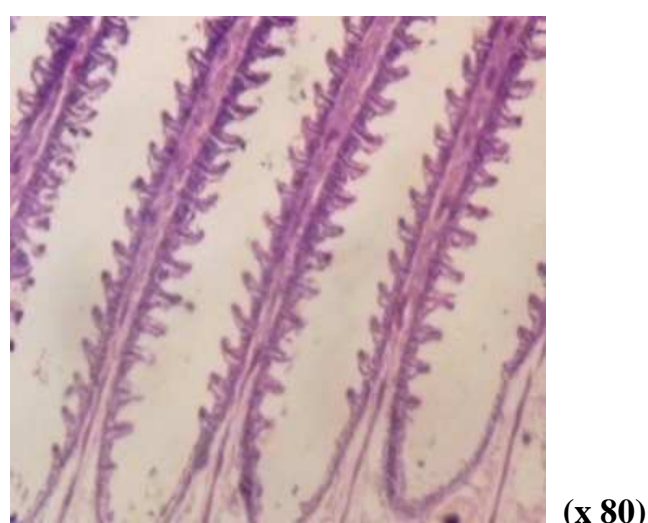

Figure 2c: Gill from TRT 3 appeared with single layer of epithelial cells covering the secondary lamellae.

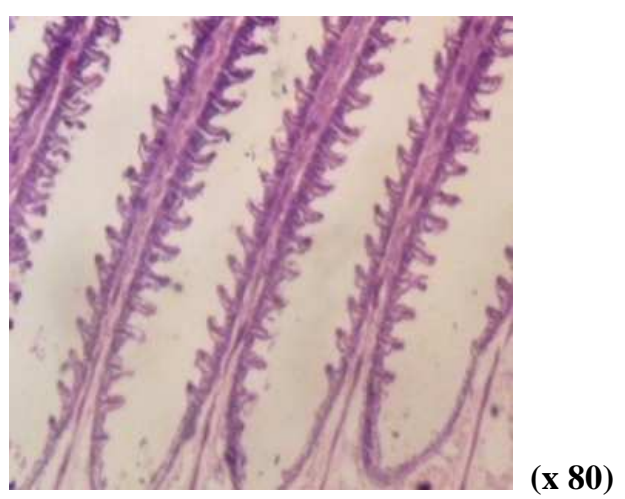

Gill from TRT 4 appeared with single layer of epithelial cells covering the secondary lamellae. 


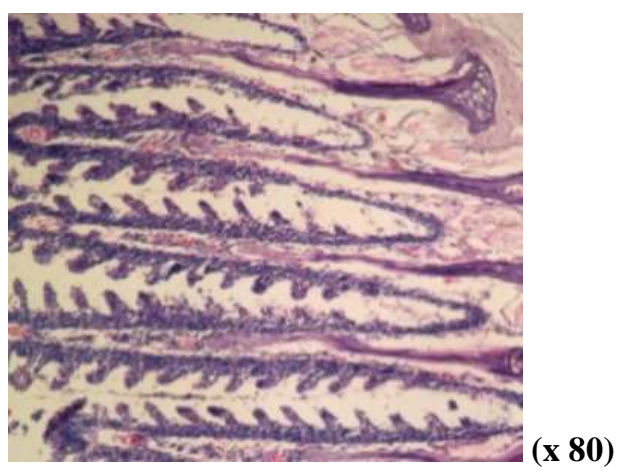

Gill from TRT 5 with haemorrhage of the capillaries in the inter-lamellar space

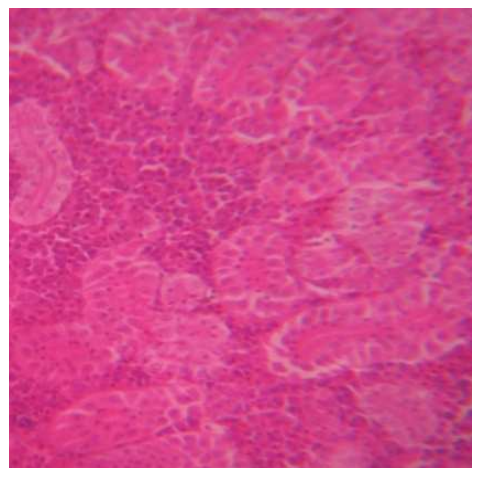

(x 80)

Figure 3: Kidney of C. gariepinus showing tubules with intact epithelium found in TRT 1 (control), TRT 3 and TRT 4.

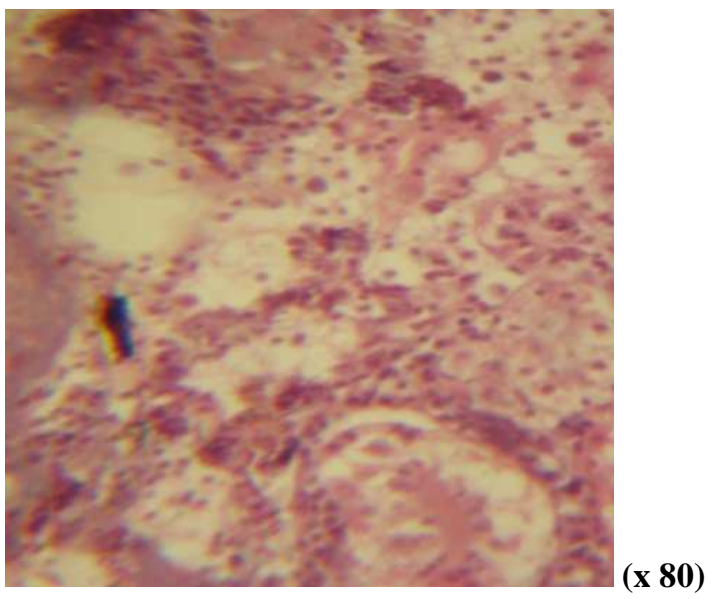

Figure 4: Kidney of C. gariepinus found at TRT 2 and TRT 5 showing tubular degeneration and necrosis 


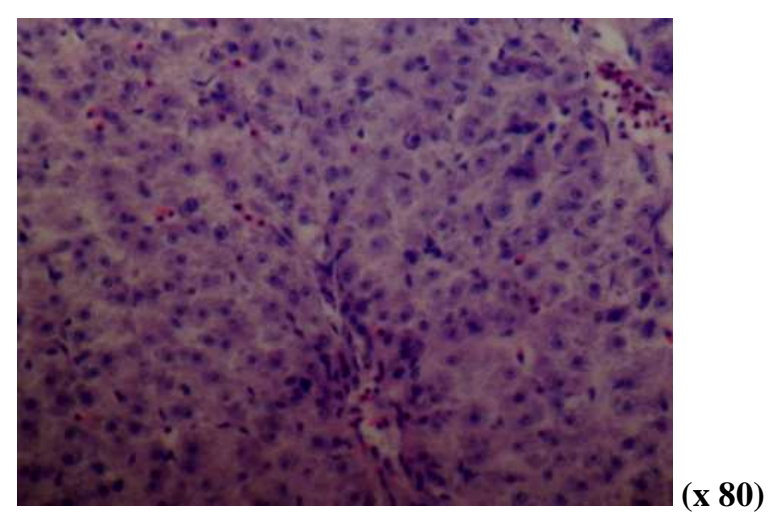

Figure 5: Liver from TRT 1 (control) showed uniform distribution of the hepatocytes.

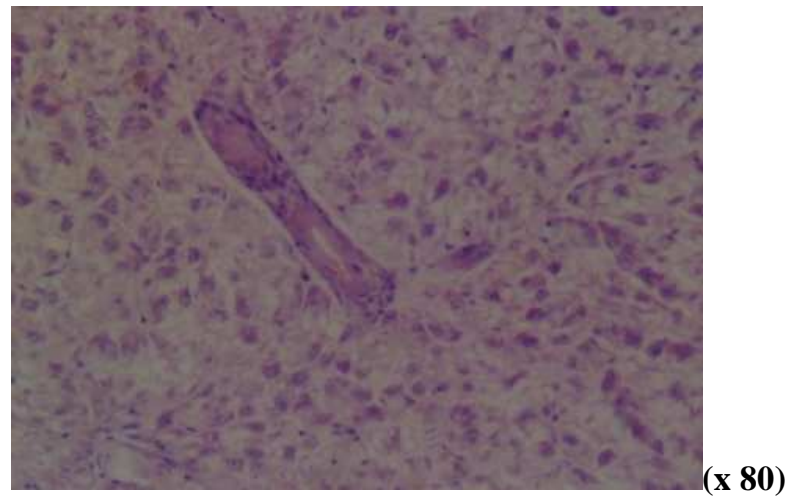

Figure 6: Diffuse necrosis of hepatocytes liver found in TRT 2 and TRT 5

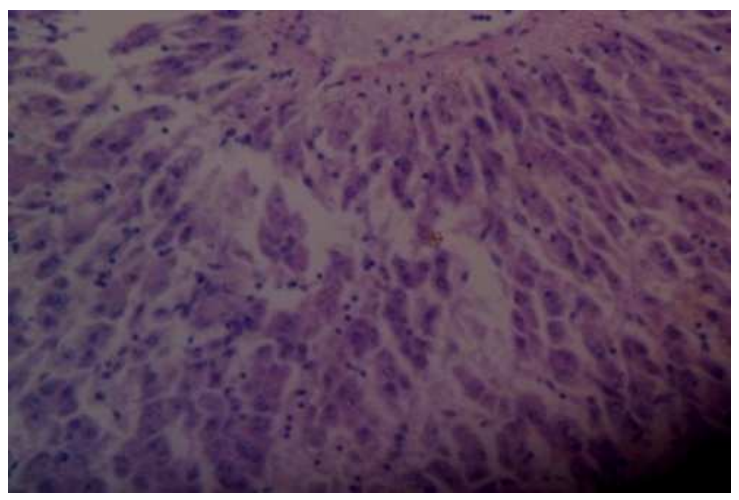

(x 80)

Figure 7: Liver from TRT 3 and TRT 4 has moderate diffuse necrosis of hepatocytes. 
The lesion found on the experimental fish at TRT 2 is an indication that mould feed can affect gills which are multifunctional organs carrying out ion transport activities, gas exchange, acid base regulation, and waste excretion via the branchial epithelium (Wendelaar, 1997). The blockage of the blood vessels with tubular epithelium degeneration observed in the kidney of the exposed fish species in this study may be due to an increase in the permeability of fish tissue to water, and increased urine output as described by Camargo (2007).

The liver is an important organ for many metabolic processes and xenobiotic detoxification. Diffuse necrosis of hepatocyte in the liver of the experimental fish can be an indication of the toxic effect of mycotoxin in the mould feed. Exposure to chemicals may lead to their accumulation in the liver and/or may cause pathological alterations (Braunbeck, 1994).

\section{Conclusion}

All the Treatments had $100 \%$ survival except TRT 5 with $20 \%$ mortality. TRT 2 which contains whole mould feed without ginger inclusion maintained $100 \%$ survival as well, which indicates that fish intake of mould feed does not inflict mortality but causes high histopathology lesion to the visceral organs.

The feed intake and protein intake in TRT 2 is considerably high compared to others. This could be attributed to the peppery taste of ginger which was absent in TRT 2 and thus influenced the high feed intake of the diet. The significant difference $(\mathrm{P}<0.05)$ observed across the group of the experimental feed in weight gain, PER, FCR, and SGR (Table 3) showed that ginger (Zingiber officinale) has the capacity to suppress the toxic effects of the secondary metabolites secreted by the mould feeds.

The study shows that mould feeds have more adverse histopathological effects on fish species than visual effect of mortality. The study further researched on available industrial waste feed ingredients that could be utilized as fish feed to reduced pressures on conventional feed ingredients which are expensive, are either imported, or in high demand as a result of their competitive usage in livestock feeds and human nutrition.

Therefore, the research profound solution of ginger (Zingiber officinale) inclusion of 30 to $60 \mathrm{~g}$ in waste-mould feeds of $100-120 \mathrm{ppb}(\mathrm{ug} / \mathrm{kg})$ Aflatoxin infected feed.

\section{ACKNOWLEGMENTS}

The Research team of this study hereby acknowledged the funding assistance received from IFSERAR, the research sector of the Federal University of Agriculture. We appreciate HEPA Aqua fish farm Abeokuta, a private farm where the research practical was conducted.

\section{REFERENCES}

A.O.A.C. 2000. Official Methods of Analysis, $\left(17^{\text {th }}\right.$ edn). Association of Analytical Chemists: Washington, DC.; 48.

Braunbeck T. 1994. Sublethal and Chronic Effects of Pollutants on Freshwater Fish. Blackwell: Oxford, UK.

Camargo MM, Martinez CB 2007. Histopathology of gills, kidney and liver of a Neotropical fish caged in an urban stream. Neotrop. Ichthyol., 5: 327-336.

Chavez-Sanchez MC, Martinez P, Moreno OI. 1994. Pathological effect of feeding young Oreochromis niloticus diets supplemented with different levels of aflatoxin B1. Journal of Aquaculture, 127: 49-60.

Eaton DL, Groopman JD. 1994. The Toxicology of Aflatoxins: Human Health, Veterinary, and Agricultural Significance. Academic Press: San Diego, California.

Effiong BN, Alatise SP. 2009. Effect of mold infested feeds on the growth and survival of Heterobranchus longifilis fingerlings. Science pub. Report and Opinion, 1(3): 914.

El-Banna R, Teleb HM, Hadi MM, Fakhry FM. 1992. Performance and tissue 
residue of tilapias fed dietary aflatoxin. Vet. Med. J., 40: 17-23.

Fratamico PM. 2008. Food Borne Pathogens: Microbiology and Molecular Biology. Horizon Scientific Press.

Gingerich WH. 1982. Hepatic toxicology of fishes. In Aquatic Toxicology, Weber LJ (ed). Raven Press: New York; 55-105.

Gujral S, Bhumra H, Swaroop M. 1978. Effect of ginger (Zingebar officinate Roscoe) Oleoresin on serum and hepatic cholesterol levels in cholesterol fed rats. Nutr. Reports Intl., 17(2): 183-189.

Hendricks JD. 1994. Carcinogenicity of aflatoxins in non-mammalian organisms. In Human Health, Veterinary and Agricultural Significance, Eaton DL, Groopman JD (eds). Toxicology of Aflatoxins. Academic Press: New York; 103-136.

Jantrarotai W, Lovell RT. 1990. Subchronic toxicity to dietary aflatoxin B1 to channel catfish.J. Aquat. Anim. Health, 2(4): 248-254.

LIoyd R, Orr LD. 1969.The diuretic response by rainbow trout to sub-lethal concentrations of ammonia. Water Res., 3: 335-344.

Mascolo N, Jain R, Tain SC, Capasso FJ. 1989. Ethnopharma cologic investigation of ginger (Zingiber officinale). $J$. Ethanoharmacol., 27(1-2): 129-140.
Masniari P. 2011. The effect of red ginger (Zingiber officinale Roscoe) extract on the growth of mastitis causing bacterial isolates. African Journal of Microbiology Research, 5(4): 382-389

Puntenney S, Wang BY, Forsberg NE. 2003. Mycotic infections in livestock: Recent insights and studies on etiology, diagnostics and prevention of Hemorrhagic Bowel Syndrome, In Southwest Nutrition \& Management Conference. Pheonix, University of Arizona, Department of Animal Science: Arizona, Tuscon; 4963.

Saber AS, Hoda AM, Hawazen AL. 2010. Protective effect of ginger (Zingiber officinale) on adriamycin - induced hepatotoxicity in albino rats. Journal of Medicinal Plants Research, 5(1): 133140.

SAS Institute Inc. 1999. SAS User's Guide: Statistics. SAS Institute, Cary, NC.

Smith JE, 1997. Aflatoxins. In Plant and Fungal Toxicants, Felix D'Mello JP (ed). CRC Press. Boca Raton, Florida, USA; 269-285.

Vasala PA. 2001. "Ginger" in Handbook of Herbs and Spices, Peter KV (ed). CRC Press, Wood head Publishing Ltd.: Cambridge, England.

Wendelaar BSE. 1997. The stress response in fish. Physiol. Rev., 77: 591-625. 